\title{
А.И. Пантюхина
}

\section{ДНЕВНИКИ ПЕРСОНАЖЕЙ В РОМАНЕ М. ШИШКИНА «ВЗЯТИЕ ИЗМАИЛА»}

\begin{abstract}
Статья посвящена анализу дневников персонажей в романе М. Шишкина «Взятие Измаила», введенных в текст основных нарраторов. Показаны способы и цели включения, формы дневников (травелог, мифотворчество). Обнаружено, что дневники персонажей фиксируют не эмпирические реалии, а феномен встречи индивида с действительностью, процесс отказа от мифотворчества, выхода к бытийным проблемам, к кризису мифов о витальном и метафизическом смысле бытия. На основе интерпретации дневников раскрываются элементы философского дискурса и модернистская стратегия повествования в романе.

Ключевые слова: М. Шишкин; современная русская проза; роман; дневник; дискурс; неомодернизм.
\end{abstract}

Интерпретация романа М. Шишкина «Взятие Измаила» остается актуальной, поскольку проза писателя проявляет общую тенденцию современной элитарной литературы к синтезу эстетик и поэтик реализма, модернизма и постмодернизма. Исследование отдельных элементов поэтики в романах писателя дает материал для выявления семантики известных форм и приемов, но в первую очередь авторской концепции человека и социальноприродного мира. Цель предлагаемой статьи - показать несводимость стратегии М. Шишкина к постмодернистской, в частности, в использовании разных литературных форм (например, дневников персонажей, включенных в роман как их подлинный текст). В работе выдвигается гипотеза, что случаи включения в нарратив романа дневниковых текстов персонажей второго ряда приближает основного пишущего героя-нарратора к неиллюзорной интерпретации реальности, к изображению ситуации встречи индивида с бытийным абсурдом. М. Шишкин в дневниковых фрагментах выходит за рамки психологического анализа пишущих персонажей, включая их версию реальности в контекст философской рефлексии о жизни и слове пишущих нарраторов (писателя Михаила и адвокатамемуариста Александра Васильевича). В романном многоголосии авторская концепция поддерживается и опровергается как двойниками-нарраторами, близкими зоне авторского слова, так и голосами самой жизни.

Дневник - это жанр документальной литературы, главной особенностью которого является последовательная фиксация событий внутренней и внешней жизни человека в письменной форме по дням [1. С. 707]. Принципиальная возможность дневника небольшой разрыв между событием и его фиксацией, процесс письма хронологически параллелен процессу реальности, что отличает его от мемуаров. В слове закрепляется непосредственность, правдивость восприятия реальных фактов пишущим, создается эффект подлинности. Дневник, в отличие от писем и мемуаров, не имеет прямого адресата [2. C. 9], это обращение пишущего к самому себе, что свидетельствует и об откровенности, невозможной при обращении к реальному адресату, и об особой герменевтической позиции - интенции к пониманию окружающего текучего мира. Опираясь на исследо- вания Е.Г. Местергази [3. С. 15] и М. Михеева [4. С. 28], выделим функции дневникового жанра:

1) гносеологическая - познание себя и окружающей реальности, здесь важен отбор событий, имеющих ценностное значение для автора дневника, а главное - оформление в слове, «освоение» явлений бытия;

2) функция сохранения в тексте следа бытия и внутренней жизни, документация своей идентичности как подтверждение непрерывности своего «я» $[5$. C. 56];

3) мифологизирующая (психотерапевтическая; культурно-игровая) функция, связанная со способностью текста пересоздавать реальность и самого пишущего, фиксировать желаемое, создавать автомиф или даже занимать позицию писателясочинителя [3. С. 15], налаживания вербальных «мостов» с реальностью;

4) квазидиалоговая функция - обращение к «идеальному», несуществующему читателю.

Дневниковая форма в художественном произведении имитирует личный текст персонажа, повествование получает модальность записей для себя. Будучи вымышленным, дневник сохраняет семантику правдивого воспроизведения жизненных явлений. Документальность в литературе ХХ в. имеет разную семантику в разных эстетических парадигмах. В неклассической литературе дневник используется как форма выражения предельно субъективного восприятия реальности или же представления об отсутствии реальности как таковой и о ее замещении текстом. Но популярность документальной литературы говорит о кризисе нереалистических эстетик, констатирующих неясность или множественность смыслов бытия [5. С. 200], когда «действительность неожиданно оказалась фантастичнее вымысла, а факты - красноречивее слов» [4. С. 14]. Простое описание факта дает голос самой жизни, он более широк и глубок, нежели авторская концепция [7. C. 153].

Мы видим возможности прочтения семантики дневникового жанра и в философском аспекте. В феноменологии Э. Гуссерля и экзистенциализме М. Хайдеггера актуализирована потребность субъекта в интерпретации бытия как условии существования. Дневник как я-письмо-для-себя есть проявление интенциональности человеческого сознания. В фе- 
номенологии Э. Гуссерля сущности явлены в конкретных феноменах бытия, которые существуют в реальности сознания. Сознание - это диалогические отношения субъекта и объекта [9. С. 370], прояснение сущности для себя. В письме человек проявляет объект, и только познанное подлинно явлено [10. C. 183-187]. Дневниковая форма актуализирует присутствие (М. Хайдеггер) человека в конкретном проявлении бытия, а присутствие и есть принцип истинного существования. Дневник является периодичным высказыванием о бытии, «модусом толкования» бытия [11. С. 153-166]. Таким образом, дневник есть акт существования, контакт с меняющимся бытием (с его проявлениями для человека). В философии постструктурализма и эстетике постмодернизма, напротив, выдвинут тезис, что в письме уничтожается понятие о голосе, источнике слова, уходит субъективность и телесное присутствие автора. По мысли Р. Барта [12. С. 384-391], Ж. Деррида [13. С. 132], всякий словесный текст, закрепляя познанный феномен, пересоздает реальность, но вытесняет ее и становится инструментом мифологизации бытия.

М. Эпштейн, развивая грамматологию Ж. Деррида, предлагает антропологическую интерпретацию письма, что важно для понимания дневника как следа человеческого бытия: «Скрипторика < ..> ставит следующий вопрос: Кто есть тот, Кого нет в письме? Зачем он живое свое бытие во плоти, в голосе и жесте меняет на свой отдаленный след? Скрипторика - это антропология, психология и персонология письма, именно в его радикальном отличии от речи, в его “не-физичности" и “неметафизичности”» [14. С. 128]. М. Эпштейн обосновывает процесс писания как попытку преодоления человеком «невроза времени», «бегства от настоящего», желания забыть себя в написанном, одновременно оставляя след. «Человек - это создаваемые им формы самоотсутствия, формы самовыражения и самостирания (в их одновременности)» [Там же. С. 132]. Как утверждает исследователь, «...человек создает мир знаков, потому что он сам неполон, как знак, он местоблюститель Отсутствующего, он замещает кого-то Другого, Совершенного и Безгрешного» [Там же. С. 134], а «письменная мотивация возникает вместе с саморефлексией, расколом себя на субъект и объект». Эти положения М. Эпштейна важны для объяснения того, почему в романе Шишкина писание дневника утверждает как постмодернистское отсутствие субъекта, его расподобление, так и феноменологические присутствие, понимание временности и бесследности существования.

Направленность дневника на фиксацию повседневной жизни человека актуализирует проблему человеческого бытия во времени, обнаруживается связь интимной жизни человека (биографического времени) с историческим временем (не конкретным, эмпирическим, а с временем большой истории, где теряется значимость частной жизни), а также временем философским («эоном» Платона) как выход к проблеме человеческой жизни перед лицом смерти.
В романе «Взятие Измаила» в субъективированное повествование разных нарраторов включены тексты персонажей, маркированные как дневники. Обращение к дневнику и отказ от него должны приблизить к пониманию природы текстового сознания человека, к пониманию бессилия личных текстов и текстов культуры перед реальностью, разрушающей картину мира интуитивным ощущением бытийного абсурда. Приблизиться к поставленной в работе цели позволит решение следующих задач: объяснить причину выбора «пишущих» дневник персонажей; обнаружить место дневников в наррации романа (предмет дневникового анализа); понять сюжетную функцию введения и прерывания дневника, его трансформацию в поток сознания.

Философия письма и слова в творчестве М. Шишкина, по мнению многих исследователей (Ю. Брюханова, С. Лашова, Г. Нефагина, С. Оробий, Ю. Шатин), - главная тема и метасюжет всех его романов (С. Лашова), что объясняет стремление писателя к полидискурсивности [15. С. 6], использование нарративных коллажей, обращение к разным историческим эпохам, разным жанрам (письма, мемуары, протоколы, отчеты о путешествиях, медицинские, следственные и прочие заключения). Не менее часта в прозе М. Шишкина имитация документальных текстов, принадлежащих персонажам. Роман «Всех ожидает одна ночь» («Записки Ларионова», 1993) строится как мемуары дворянина XIX в.; в романе «Венерин волос» (2005) значительную часть текста составляют псевдодокументальные тексты: протоколы допросов беженцев, дневник певицы Беллы; «Письмовник» (2011) - эпистолярный роман, близкий дневнику, продолжающийся после смерти одного из героев. Роман «Взятие Измаила» (1999) в значительной части воспроизводит автобиографию для энциклопедии, превращающуюся в мемуары (curriculum vitae бывшего адвоката), в роман вводятся эго-тексты персонажей - письма Михаила, а также дневники (жены судебного чиновника Ольги Вениаминовны и врача-патологоанатома Мотте). Обращение писателя к дневниковым формам, на наш взгляд, связано с двумя взаимоисключающими эстетическими принципами прозы М. Шишкина. С одной стороны, с представлением о невозможности истинного понимания причин и следствий явлений реальности; возможность множества субъективных версий - эстетика, близкая постмодернизму. С другой стороны, дневниковые тексты показывают данность человеческому сознанию феноменов бытия. В романах М. Шишкина тексты фиксируют следы контакта конкретного человека с конкретным проявлением реальности, но и провоцируют мифологизацию персонального опыта индивида, соотнося единичное, настоящее с универсальным, вечным. Автору такая склонность персонажей и нарраторов дает возможность показать судьбу индивида, а ее уникальность осмыслить в контексте «большой» истории и метафизического бытия.

Повествование в прозе Шишкина онтологично, оно порождает художественную реальность, художественный мир держится на рассказе о нем. Иссле- 
дователи указывают, что у Шишкина «экзистенциальной значимостью обладает лишь то, что обрело себя в слове; бытие «записанного» персонажа более реально, чем эмпирическое существование «незаписанного» автора или читателя [16. С. 109]. Но при этом писание есть бегство от дисгармоничности жизни; часто в романах подчеркивается иллюзорный характер диалога, что указывает на доминанту в мироощущении писателя витальной энергии [17. C. 480], хотя слово является хранителем витального импульса. Содержательно подчиненность наррации риторическому целому и неопределенность внутритекстовых границ, их нарушение делают поэтику романа «Взятие Измаила» «поэтикой разрыва» (термин Ю. Шатина; см. также Т. Кучину, С. Оробия, В. Шуникова), разрыва «на уровне акторального и аукторального повествования» [18. С. 314], т.е. разрыва между «повествовательным я» и «действующим я». Повествовательное «я» переходит в другое действующее и пишущее «я». Это относится и к дневниковым формам, поскольку они размыкаются в другие повествования без каких-либо графических маркеров. Дневник Ольги Вениаминовны - в письмо мужчины, которого она встретила на курорте; дневник Мотте трансформируется в ирреальный сюжет встречи героя с Богом, фиксируя поток сознания персонажа (т.е. формально перестает быть дневником).

На наш взгляд, это не столько разрыв, сколько синтез, желание автора любой текст сделать текстом обо всем и обо всех, не только о настоящем, но и о вневременном. Поэтому сюжетные мотивы романа устойчивы и «прорастают» друг в друга в разных историях, в разных «голосах». Шишкин, сохраняя формальную сосредоточенность на одном персонаже, выбирает разные фокусы восприятия, собирая свою «коллекцию» не только моментов бытия, но и коллекцию голосов, которые «поют в унисон» и доказывают писателю, нарратору и несправедливость жизни, и греховность человека, и возможность оправдания. «Расширение» интерпретирующего сознания автора-персонажа - это герменевтические «круги» в процессе осознавания бытия в письме, и фантазии развертываются как варианты и контраргументы понимания автора. В «Эпилоге» (в форме письма Михаила жене) обретенная конкретность времени и пространства (эмиграция из постсоветской России) и акт рождения сына, связывающий автора-нарратора с Тут-бытием, все же размыкаются до всеобъемлющей потерянности героя-нарратора, завершая роман вопросом «Где я?» [19. С. 477].

Магистральный сюжет романа «Взятие Измаила»- сюжет познания смысла собственной жизни, жизни близких и знакомых людей в контексте хаотичной истории. Главный персонаж романа - писатель Михаил, который, во-первых, в процессе писательства выходит к познанию смысла жизни человека как такового, а также к пониманию сущности бытия. Во-вторых, герой романа - носитель креативного сознания, готового к воображению исчезнувшего и возможного, к перевоплощению в Других, в иные способы существования. Система персонажей и принцип их введения в роман обусловлены гносеологическими задачами нарратора-персонажа. В романе воспроизводится многолетняя попытка Михаила написать роман, не сводимый к одной сюжетной коллизии; но созданию текста мешают изменяющееся историческое время и вторжение природных сил (смерти близких), а также внутренние изменения (текучесть привязанностей, страстей). Сюжеты прерываются, истории персонажей дискретны, поскольку нарратор, возвращаясь к ним, варьирует их модальность. Главный нарратор-персонаж, проявляя статус Автора, эксплицитно фиксирует сюжет письма, снимая принадлежность текста персонажам. Текст нарратора - не мемуары и не воспоминания, а воспроизведение своего творческого самосознания, создающего новые центры видения, Я-Другого, по М. Бахтину [20. С. 64]. Бытие открывается не в индивидуальном сознании, но и не в хоре голосов, а в диссонансе рецепций бытия и понимания бытия. То есть автор в романе выступает как принципиально диалогическое сознание, как носитель антиномического понимания жизни, все персонажи вымышлены им и воплощают позиции близкие или, напротив, противоположные. Их идеи, ценностные позиции, ситуации жизни повторяют судьбу главного героя, позволяют увидеть «себя» в другом времени, в другом ракурсе, объективно выводя личную судьбу к обобщению. Обнаруживается повторяемость и несходство экзистенциальных положений: сопротивление (Евгений Борисович Д.), эскапизм (Мотте), принятие и прощение (Александр Васильевич), что выражает варианты экзистенциального выбора героянарратора и его близких.

В романе доминирующий принцип «я-повествования» связан с тем, как внутренний монолог главного героя, писателя Михаила, включен в попытки написать роман. Отличие текстового закрепления внутреннего монолога от дневниковой формы видится в отсутствии регулярности и нарративной последовательности изложения истории жизни, в отсутствии сюжета создания текста. К тому же в истории Михаила много ретроспективных эпизодов, но они не выстраиваются в сюжет воспоминаний, а фиксируют переживание состояний прошлого здесь и сейчас, что близко дневниковому принципу синхронности текста и состояния я-повествователя. Тем не менее, в отличие от повествования второго нарратора, Александра Васильевича, в повествовании Михаила нет «подведения итогов», переоценки жизни. Отличие повествования главных нарраторов романа от дневниковой формы проявляется и в наличии формального адресата. Адвокат обращается то к своей больной дочери, хотя она неспособна его понять, то к воображаемым слушателям его «лекции», то к «афинянам», к которым обращались взывающие адвокаты («advoco») с античных времен; Михаил обращает свой текст жене Франческе (в том числе в посвящении романа).

В строгом смысле слова дневник в романе встречается дважды и принадлежит персонажам второго ряда. Во-первых, Ольге Вениаминовне, взрослой 
женщине, искавшей смысл жизни в телесных наслаждениях, но столкнувшейся со смертью, с властью природных законов над человеком. Вовторых, Владимиру Павловичу Мотте, врачупатологоанатому, столкнувшемуся с абсурдом мироустройства и трагически осознавшему свое бессилие пред бытием как экзистенциальную вину («неоказание помощи»). Дневники вводятся как дистанцированная от коррекции первичным повествователем форма, даже от авторского вмешательства, имитируя документальный текст, рожденный непосредственным столкновением персонажей с эмпирической реальностью, а последствием писания дневника становится открытие частным человеком трагизма своего существования и абсурдности, непознаваемости жизни.

Рамочным сюжетом повествования является стратегия устного слова, говорения - лекции («Лекция 7-я») и одновременно судебной речи (защитной, обвинительной, оправдательной), допросов (что также является одним из фактов нарушения внутритекстовых нарративных границ, границ полифонии голосов). Все истории вплетены в ситуацию суда, которая является повествовательным приемом нарратора, сочиняющего роман, чтобы подчеркнуть главную проблему - суда над жизнью, но одновременно и над собой: вины перед близкими, вины за жизнеустройство. Включенные в основную наррацию дневники переводят процесс фиксации реальности в исповедь, хотя исповедальность редуцирована тем, что в дневниках запечатляется не обретение истины, а открытие тайны жизни.

Дневник Ольги Вениаминовны композиционно включен в повествование Александра Васильевича. Он, размышляя о неизбежности человеческих грехов, вспоминает историю из своей юности, связь со взрослой женщиной, женой своего патрона. Композиционное сближение двух сознаний проявляет переосмысление Александром Васильевичем своего прошлого, разгадывание непонятого в прошлом Другого через его голос, его писание. Александр Васильевич, отчуждаясь от Ольги Вениаминовны, в переживании собственной вины ищет новое объяснение ее сближения с ним. Однако тайна отношений, тайна Ольги Вениаминовны, остается неразгаданной и постаревшим Александром Васильевичем, что потребовало включения в повествование ее голоса - не для обвинения или жалобы, а для выражения трагизма самосознания человека, оказавшегося перед концом существования. Разгадывание Александром Васильевичем эмпирического события (любовной интриги) переводится в план разгадывания Другим человеком экзистенциальной проблемы.

Включению отрывков из дневника патологоанатома Мотте (занятие символизирует сосредоточенность на патологии жизни, на рассудочном разъятии целого феномена жизни), воссоздающего ситуацию фантасмагорического путешествия в мир смерти, предшествует внутренний диалог нарратора Михаила с собой: Михаил создает в воображении мифический образ Мужа Желаний (себя самого как воплощение человеческой сущности), чья жизнь как стремление к исполнению желаний прерывается смертью, а смерть, соответственно мифической картине мира, не прекращает существование, а переводит существование в инобытие, и требуются показания на посмертном суде о прожитой жизни: что сделано и что не совершено. Это важно отметить, так как следующая за фантасмагорической картиной история Мотте с включенными в нее дневниками переводит повествование в противоположную модальность - модальность суда над жизнью. Дневники Мотте и повествование о нем включены в картину провинциальной жизни, поражающей автора дневника дикостью народного образа жизни и убеждающей в бессмысленности личного самостояния (Мотте анализирует жизнь четы провинциальных интеллигентов). Однако обращенность дневника Мотте вовне вытесняется внутренним судом над самим собой, отказом от «оказания помощи» людям и окружающей действительности (погружение в поток сознания, отказ от письма соответствует мифологизации реальности и выражению экзистенциальной вины персонажа, подобной духовной ситуации нарратора Михаила, напомним - близкого автору).

Дневники принадлежат «обвиняемым» (в дискурce суда) - «блудница» Ольга Вениаминовна и «неоказавший помощь» врач Мотте. Форма дневника не проясняет сущность бытия пишущему персонажу, но она позволяет основному нарратору выразить неигровое открытие бытия индивидом, делающее его существование трагически неисправимым. Дневники персонажей фиксируют изменение понимание бытия и трагические последствия этого. Оба дневника в роман введены без графических маркеров, слово нарратора «перетекает» в слово пишущего дневник, текст дневника завершается либо сменой субъекта (в случае с дневником Ольги Вениаминовны), либо сменой дискурса (дневник сменяет поток галлюцинаций Мотте), анализ в письменной форме вытесняется фиксацией нарратором иррациональных видений персонажа.

Ольга Вениаминовна - женщина, с которой у начинающего адвоката Александра Васильевича была любовная связь. Ольга Вениаминовна старше Александра Васильевича (ей - 40-50 лет, ему, вероятно, чуть более 20), и она жена патрона, наставника молодого адвоката, Ильи Андреевича. Образ Ольги Вениаминовны возникает в дискурсе воображаемой лекции-суда Александра Васильевича, который, размышляя о грехах и преступлениях людей, приводит примеры из своей практики. Осуждение прелюбодеяния становится основой воспоминания Александра Васильевича об Ольге Вениаминовне. Ее образ сопряжен, во-первых, с проблемой вины, сначала - ее вины за блуд и измены мужу, совращение молодого юноши, потом - вины Александра Васильевича перед Ольгой Вениаминовной, отказавшегося от спасения «ближнего», который лишь спустя время понял ее трагедию. Он смог дать другое объяснение (косвенное) адюльтера, оказавшись сам перед лицом смерти - в одиночестве воспитывая больную дочь, испытывая вину за измену жене. Он пришел к пони- 
манию личной ответственности перед тем, с кем случайно связал бытие. Во-вторых, образ Ольги Вениаминовны воплощает женское сознание, устремленное к полноте чувственного, а не метафизического бытия. Запросы женщины частны и связаны с потребностью в чувственной любви.

Ольга Вениаминовна - увядающая женщина и стремится к эмоционально насыщенной жизни. Она соблазняет юного Александра Васильевича, но в скором времени он разрывает их роман, ощущая обман Ольги Вениаминовны и вину перед своим наставником. Через год после их связи он узнает о возвращении бывшей любовницы из Франции в состоянии тяжелой и неизлечимой болезни, что открывает Александру Васильевичу причину ее стремления к страсти - близость смерти. Осознание личной вины перед Ольгой Вениаминовной сопровождается стыдом Александра Васильевича, ее осуждением и непониманием, одновременно и невозможностью ей помочь. В юности адвокат не защитил беззащитную перед смертью, не восполнил потребность в осуществлении желаний, а обвинил в нарушении этических норм.

Дневник Ольги Вениаминовны не включает рефлексию о незаконной с социальной точки зрения любовной связи (что свидетельствует об истинности подозрений Александра Васильевича в имитации ею любовного чувства), он начинается как травелог, описывая путешествие по Франции в поиске новых впечатлений. В дневнике отсутствуют даты, но есть маркеры времени и пространства - слова «сейчас» и «сегодня», которые представляют образ длящегося, застывшего момента, подобно ощущению человека во времени, ощущению настоящего. В дневнике Ольги Вениаминовны можно выделить три семантических поля, которые показывают и процесс болезни, и процесс самоотчуждения, власть биологии над человеком. Первое семантическое поле: травелог, описание другой страны, географии, культуры. Здесь пишущий сосредоточен на внешнем и объективном. Второе - любовный сюжет, курортный роман с Николаем Александровичем в попытке реализовать миф о любви, торжествующей над абсурдом жизни. Третья часть дневника снова обращена вовне, к описанию карнавала в Ницце, обеда в ресторане, связи со случайным мужчиной, но эта мнимая полота жизни помещена в атмосферу знания о смерти. Готовность к чувственному наслаждению престает быть и игрой, и нарушением этических правил. Этому соответствует устранение личностного сознания, описания чувств вытесняются фиксацией проявлений жизни внешней. Встреча героини с конечностью собственного бытия порождает как буквальное бегство (из России во Францию), так и бегство в текст, форму, по М. Эпштейну, самоотсутствия, самостирания, бегства от настоящего.

Начало дневника соответствует приезду Ольги Вениаминовны в Ниццу, курортное пространство, противопоставленное городскому, обыденному. Поэтому ведение дневника именно в этом месте есть желание зафиксировать полноту жизни в описаниях ландшафта, природы, погоды, досуга и еды. Ольга Вениаминовна отмечает этимологию названия города - «Ницца-Никея» - это город победителей, завоевателей. С одной стороны, ирония подчеркивает бессилие героини, ее «проигрыш» в городе вечного отдыха и радости, который не соотносится со смертью. С другой стороны, нравственная победа Ольги Вениаминовны над болезнью проявляется в отказе от страха и попытках любить жизнь.

Дневник Ольги Вениаминовны утверждает ее присутствие в мире - в описании объектов и явлений курортного города с указанием географических данных, особенностей климата. Фиксируемый мир характеризует внутреннее состояние героини, но не утверждает понимание. Далее дневник становится более личным и субъективным, но исключающим размышления о своих чувствах, о прошлом, отсутствует мифологизация радости и «словесная сотериология». В дневнике редуцируется правдивое я, но объективность письма открывает ее присутствие в стремлении не говорить о своей трагедии.

Важное место в дневниках занимает любовный сюжет взаимоотношений с таким же отдыхающим, биологом-коллекционером Николаем Александровичем. Любовная история опирается и на банальный сюжет о курортном романе, и на чеховскую и бунинскую традиции изображения хрупкости чувства и трагичности любви. М. Шишкин обнаруживает разность сознаний героев, их мироощущения, что осложняет духовное соединение материалиста (Николай Александрович - биолог) и человека сенсуального (но не метафизического). Ольга Вениаминовна иронизирует над своим соседом, высокомерно подчеркивает его наивность, его веру в порядок и смысл жизни, но она нуждается в Николае Александровиче, который становится для нее не только возможностью бегства от одиночества, реализации ее надежды на любовь, но и носителем веры в порядок если не бытия, то эмпирической жизни людей. В самой же Ольге Вениаминовне эта вера нарушена. Поначалу в Николае Александровиче она видит наивного человека, не столкнувшегося с трудностями жизни, но после узнала о его трагедии смерти сына. Это позволяет ей переоценить своего партнера, но снова дневник фиксирует непонимание того, как отец смог жить после смерти сына, более того, как он мог радоваться жизни после осознания своей беспомощности перед смертью. Способность героини сопереживать сталкивается с загадкой Другого: его силой жизни или эмоциональной черствостью. Прикоснувшись к трагедии Николая Александровича, Ольга Вениаминовна сама отказывается от откровенности с ним, от признания в своей болезни. В ней тоже остается загадка, не разгадываемая в дневнике: неспособность к проявлению подлинного сознания, неверие, что встреченная любовь может возродить ее. Поэтому влечение к другому в дневнике не получает развития. «И в ту минуту, когда я ответила вам «нет», в ту самую секунду вдруг так пронзительно захотелось умереть. Послушай, любимый мой, ты все-все когда-нибудь поймешь» [19. С. 97]. С одной стороны, женщина 
не ставит мужчину в положение не оказавщего помощьь, так как помощь оказать невозможно; с другой стороны, она мифологизирует свою трагедию, неразрешимость ситуации, переводя ее в романтичную тайну. Это подчеркивается театрализацией описания расставания с Николаем Александровичем, делающей поэтичным курортный роман с опорой на образцы русской классики. Ольга Вениаминовна создает в дневнике миф о трагической любви, словесно замещая проявления безобразности болезни и приближения смерти.

В дневнике и сама героиня, и автор осознают относительность понимания реальности. Ситуация, в которой героиня разбивает зеркало, имеет символический смысл, соотносится, во-первых, с невозможностью выразить себя в дневнике (дневник как форма вглядывания в себя), во-вторых, с распадом собственной личности, связанным с ускорением ощущения смерти Ольгой Вениаминовной, отчуждение в финале дневника выразится в переходе к повествованию от третьего лица. Выше мы говорили о причинах приезда в Ниццу как попытке эскапизма Ольги Вениаминовны, ее желания жить полной жизнью. Но дневник фиксирует невозможность освободиться от болезни, отказ от иллюзий - описания курортного быта соседствуют с краткими упоминаниями деталей своей болезни: записи о посещении врача в Париже, употребление лекарств, описание плохого самочувствия, представление о себе как бездуховном теле в бесстрастных деталях болезни как «галочки в медицинской статистике» [19. С. 91]. Часто Ольга Вениаминовна сталкивает витальные образы и образы смерти, которые соединяются в сцене карнавала. После отъезда Николая Александровича героиня отправляется на карнавал, именно тогда меняется повествовательная точка зрения, повествование от третьего лица редуцирует личный взгляд на реалии, доверие собственному сознанию редуцируется. С утратой интенции к любви возникает погружение в стихию коллективной телесности, что подчеркивает синтаксис: короткие предложения соответствуют и ускорению ритма погружения в карнавал, но и отказ от рефлексии, от осмысления жизни, чреватой смертью. «Расчесывала волосы. Пудрилась <..> Она выхватила у кого-то букет и сама стала хлестать им направо и налево. Толпа вышвырнула её к какому-то ресторанчику. Она, смеясь, заказала жаркое, не глядя, просто ткнув пальцем в меню...» [Там же. С. 98].

Дневник перетекает без каких-либо графических маркеров в письмо мужчины, который встретил ее на улице, довел до своего номера и воспользовался ее телом, руководствуясь принципом Ольги Вениаминовны: «Все мы умрем, брат. Главное - умереть молодцом! Надо загребать жизнь обеими руками» [Там же. С. 99]. Растворение в карнавале жизни подчеркнуто не только сменой повествовательной позиции, но и семантикой насилия в телесном проявлении витальности.

Дневник Ольги Вениаминовны подчеркивает ее самоотчуждение, редукцию осознания болезни и приближения смерти. Это и рождает дневниковую тайну, поскольку Ольга Вениаминовна, избегая ре- флексии, фиксирует лишь соучастие в потоке жизни, подчиняется общему переживанию жизни как праздника. Поэтому и в «романе» с Николаем Александровичем она отчуждается от полноты собственных переживаний, описывает со стороны: «Всё вышло хорошо, как нельзя лучше, как и должно было быть, только в самом конце тебя чуть подвели нервы - хлопнул дверью так, что зазвенела люстра» [Там же. С. 97].

Включение в роман дневника Мотте также связано с ситуацией суда, осуждением «неоказания помощи». Юридически это неоказание помощи ближнему, экзистенциально - осознание беспомощности человека перед враждебностью бытия. В отличие от женщины, Ольги Вениаминовны, Мотте наделен этическим чувством вины, является носителем личностного сознания, он врач, обращенный к патологии самой материи жизни (врач-патологоанатом). Мотте, во-первых, отказался от служения своей профессии как спасения людей, поняв бессмысленность этой миссии. Во-вторых, оказавшись в провинции и включаясь в жизнь семьи больного чиновника Д. и его жены, он со временем понимает бессмысленность своей помощи и также покидает дом интеллигентов, сопротивляющихся бесцельности и бездуховности провинциального образа жизни.

Сюжет Мотте представляет советскую эпоху середины XX в. как торжество неличностного, массового сознания, новой первобытной культуры в народе. Обращенность к внешней жизни в первых фрагментах редуцирует семантику дневника как выражения индивидуальной внутренней жизни. Однако личностное выступает в гипертрофированной реакции автора дневника на внешние реалии, показывая усиливающуюся дезориентацию личности в обессмысленном существовании, обусловливает восприятие исторической реальности в аспекте мифа. Мифологизированное время и пространство в дневнике Мотте напоминают архаическую эпоху, статичную национальную и общечеловеческую жизнь, из которой невозможно выбраться. В его дневнике тутбытие размыкается до хронотопа «déjà vu»: не середина XX в., а время архаическое, подчиненное природным циклам (жизни и смерти), а не социальной этике или историческим идеям, это мир «самоедов», языческий мир, жестокий по отношению к отдельному человеку. Мотте воспринимает себя не лечащим врачом, а пророком, обличающим людей в несоответствии их земной жизни высшим законам. Цель обличений пророков - призвание людей к пониманию отступления от божественных законов, т.е. спасение их. Мотте же обличения помещает в дневнике, в тексте для себя, призванном обосновать неверие в спасение народа. Претензии Мотте направлены не только к социальному абсурду провинциальной жизни, он обобщает факты до констатации онтологического несовершенства, собственное бессилие в профессиональной деятельности врача он возводит к онтологическому хаосу (неизбежности болезней и смерти).

Как и для Ольги Вениаминовны, дневник для Мотте становится пространством эскапизма: герой 
стремится уйти от анализа социальной жизни, он выбирает повествовательную игру в описании своего пребывания у Д. и Марии Дмитриевны. В отличие от дневника Ольги Вениаминовны, в котором создается антитеза жизнь-смерть (детали болезни преодолеваются витальными образами природы, чувствами любви и пр.), дневник Мотте создает картину национального мира как сформированного природным хаосом, генетически амбивалентного, где продолжение жизни сопровождается ее разрушением.

Дневники Мотте в романе даны не обособленно, а включаются отдельными цитатами - комментариями событий реальной жизни, более подробно описанными повествователем, т.е. отбор осуществляет не Мотте, а нарратор, показывая и ограниченность точки зрения героя как подсудимого, осуждаемого за «неоказание помощи ближнему», и изменение его ценностной позиции в ходе сюжета. Предметами наблюдений окружающей реальности и внутреннего мира героя становятся, во-первых, мифологизированное описание провинциально-дикого образа жизни, во-вторых, эпизоды жизни с потерянной возлюбленной, лаконизм изображения утраченного прошлого свидетельствует о силе душевной травмы, сформировавшей неприятие реальности, в-третьих, описание жизни у Марии Дмитриевны и Д., сначала ироничное, потом - сочувственное. Вхождение Мотте в поток повседневной жизни дома, уход за подброшенным ребенком становятся внешней причиной того, что герой перестает писать дневник. Этот факт доказывает, что для Мотте дневник был формой самооправдания, а не исповеди. Как только возникает контакт с реальностью, попытки преодоление малых проблем, человек перестает оправдывать свое неучастие («неоказание помощи») и начинает «соучаствовать» с жизнью. Когда реальные обстоятельства обессмыслили усилия Марии Дмитриевны и Мотте по спасению ребенка (пришлось отдать ребенка родителям - в «дикие» условия), Мотте уже не может в дневник вносить инвективу жизни, но невозможно и признание в своей вине, и он отказывается от дневника, как и от соучастия в жизни близкой ему четы стариков. Дезориентация героя в реальности погружает его в мифы подсознания, в бегство не только из провинции, но из эмпирической реальности в метафизическую. Поэтому вторая, притчевая и фантастическая часть сюжета - встреча героя с Богом - дана нарратором не в форме дневника, а в форме притчевого мифологизированного повествования.

В дневнике Мотте видел себя в роли путешественника, антрополога, открывающего природу человека, биологическую доминанту существования. Мотте изучает местный народ, словно зоолог животных, понимая, что он ничего не изменит в этой жизни: «У всех детей рахит, микромелия. При этом обычный размер тестикулов аж седьмой. От грязи, как следствие, кожные болезни - чесотка, лишаи, коросты, фистулы, язвы. А сколько пришлось насмотреться всяких уродств, патологий» [19. C. 227]. С помощью повествовательной игры мифологизируется реальность, герой определяет свое от- ношение к национальной жизни, формулирует свою чуждость ей. Но и окружающие воспринимают Мотте как чужого: «Ты, бачка, не наш, не русский» [19. C. 226]. Такая повествовательная игра отдаляет героя от действительности и от собственного «я». Он пишет: «вообразим себя Миддендорфом, Гумбольдтом, на худой конец Палласом» [Там же. С. 225] - и сразу отказывается от этой игры в пользу реальности: «Хотя я - вот он, здесь», утверждая первостепенность наличного бытия, а «Паллас - где он?» [Там же. С. 226]. Но стремления жить «здесь» не исполнимы: герой постоянно сталкивается с проявлениями социального насилия, хаотичности и безответственности людей: в первый же день его обворовывают, после отъезда избивают в тюрьме.

Внутренняя жизнь Мотте входит в воспоминания о прошлом только один раз как «прорывание» истинных переживаний, от которых герой стремится убежать. Он описывает эпизод встречи с любимой девушкой - опоздание на поезд, принятие ванны. Лаконизм усиливает боль утраченного счастья, безэмоциональность показывает бегство героя от воспоминаний, но невозможность избавления от боли утраты: «То забудешься, то вдруг опять нахлынет» [Там же. С. 233]. Прошлое не эстетизируется, не мифологизируется, но осознание смерти как онтологического закона лишает жизнь смысла. В дневнике мотивируется единственный путь спасения - бегство в иное пространство. Если Ольга Вениаминовна устремляется в витальную Ниццу, то Мотте сначала убегает в русскую провинцию, где только усиливается ощущение жизни как абсурда.

Поэтому попытки сохранить культуру в быту (семейство Д.) кажутся Мотте смешными и нелепыми в окружении дикости (маски для лица Марии Дмитриевны, чистые скатерти, умные беседы, забота друг о друге старых людей, напоминающих литературные прототипы Филемона и Бавкиды). В дневнике он фиксирует непонимание усилий Марии Дмитриевны, противопоставляет ей свою отстраненность. Но за границами дневника - в объективном повествовании Мария Дмитриевна открывает Мотте необходимость сопротивления абсурду жизни, Мотте начинает помогать Марии Дмитриевне, вместе с ней пытается спасти ребенка, украденного сумасшедшей женщиной, не способной рожать детей. Появляется надежда на спасение хотя бы одного человека. Победа жизни над текстом проявляется в коррекции своего прежнего мифа о смертоносности жизни, хотя последние записи героя сводятся к простому «Сереженька заболел» [Там же. С. 240]. Далее следует повествование от третьего лица, сохраняющее психологическую точку зрения Мотте: «ему вдруг стало страшно, что Сереженька прямо сейчас, у него на глазах умирает, а он ничего не может сделать» [Там же. С. 240]. Герой понимает, что ситуация, в которой он несет ответственность за смерть другого человека, повторяется, и он чувствует свое бессилие. Такое сочувствие и соучастие жизни впоследствии осмысляется героем как принятие иллюзий, поскольку усилия оказались бесплодными. Частный случай доказывает бессмысленность вмешательства в жизнь: 
подброшенный несчастной матерью ребенок оказался украденным, родители его нашли и вернули себе, обрекли на то «дикое» существование, которое вызывало у Мотте неприятие и отчаяние. Вариант спасения оказался не только невозможным, но и преступным в соответствии с правом реальной жизни. На этом формально заканчивается включение дневника Мотте в роман.

Проблема оказания помощи неразрешима, поскольку помощь - навязывание другому своего способа существования. Но этическое чувство личности не может отказаться от «заботы о бытии», от экзистенциальной вины за абсурд бытия. Мотте отказывается от помощи Марии Дмитриевне, отправляясь на вокзал, чтобы выбраться из бессмысленной жизни. Но его отъезд в наррации повествователя изображается, с одной стороны, как потеря ориентации, погружение в онейрическое состояние, с другой стороны, как выход в метафизическую реальность, близкую сакральной мифической сфере. Мотте не может покинуть реальное пространство - кассы на вокзале не работают, отправляется в городской парк, где встречается с сумасшедшей старухой, которая просит его о помощи. Так в сюжет Мотте входит ситуация неоказания помощи и осознания вины. Это имеет модальность как реальной ситуации (поскольку Мотте арестовывают и отводят в милицию, что может объясняться какимто происшедшем преступлением), так и метафорической, созданной галлюцинациями человека, остро почувствовавшего личную вину за оставляемую без помощи жизнь. Экзистенциальная вина трансформируется в обращение сознания Мотте к метафизической инстанции, которая могла бы вмешаться в абсурд реальности. Дезориентированность мешает Мотте понять проиходящее с ним: его арестовывают, избивают и сажают в тюрьму, не объясняя, как ему кажется, виновен ли он в каком-то преступлении или он арестован за неоказание помощи. Тюремное наказание героя, с одной стороны, говорит о социальном абсурде, с другой стороны, проявляет смену этического вектора в сознании Мотте: он переживает личную вину перед абсурдом действительности и обращается к высшей силе для помощи людям, которых так презирал. Поиски ответа на вопрос о природе социального хаоса выражаются в фантазийной встрече Мотте с Богом. Воображенная картина, с одной стороны, опирается на известный сюжет спасения еврейского народа из рабства (исход из Египта), с другой стороны, сюжет деконструируется и демифологизируется нигилистическим сознанием современного человека.

Воображаемая встреча с Богом Мотте, готового быть пророком, не только обвиняющим, но и спасающим людей, выводит повествование к объяснению национальных и личных бед как повторяющихся и неуничтожимых. Мотте, осуждаемого за неоказание помощи ближнему, призывает Бог, услышавший о страданиях своего народа. Мотте не Моисей, он не выводит народ, а только взывает к Богу. В понимании Мотте Бог бессилен спасти жертв, спасение должно исходить от палачей, от воли фараона и его народа, исполняющего волю фараона. Побудить людей отказаться от зла Бог может только наказанием, причинением зла и фараону, и египтянам, жертвам фараона. Десять казней, насылаемых Богом на египтян, для Мотте предстают не только показателем бессилия Бога, но и показателем неабсолютности божественной воли. В фантазийном сюжете сознание Мотте не обретает ориентира, более того, лишается иллюзии спасения в личных и созданных человечеством мифологиях. Равно неабсолютны иудейская и египетская мифологии о возможностях сакральной силы.

Если дневник призван показать трагедию конкретного человека, то продолжение истории Мотте в фантастическом дискурсе метафизического диалога с Богом, трагедии онтологического масштаба, свидетельствует о том, что Мотте - это знак сознания пишущего автора, авторского философствования, авторского гносеологического сюжета. Мотте оказывается несоразмерен бытию, и Шишкин изобразил ситуацию кризиса индивидуального сознания, уповающего на спасение вне физической реальности.

Функции дневников в романе «Взятие Измаила» выходят за пределы раскрытия внутреннего мира персонажей, раскрытия причинно-следственных связей сюжетных ситуаций. Дневники персонажей в роман вводятся не полностью, что делает их не документом, не текстом, омертвившим и тем сохранившим факты жизни, а живым, незавершенным актом познания жизни. Кроме того, дневники в романе «Взятие Измаила» связаны с другими формами высказывания о жизни как персонажей, так и нарраторов, что нарушает жесткую иерархичность ценностных позиций в романе.

Дневники, несущие эмпирический опыт частных людей, введены в систему экзистенциальных коллизий и философских проблем всего романа и важны как варианты решения этих проблем. Непосредственно закрепленный в тексте дневника опыт встречи индивида с реальностью позволяет автобиографическому нарратору разрушить монологизм сознания, выстоять (в отличие от Мотте) перед вопросами бытия. Дневник как документ феноменального опыта встречи с жизнью подчеркивает стремление автора романа к преодолению предзнания, к повторению текстовых объяснений жизни. Однако дневник, несмотря на его космизирующие возможности, может быть способом бегства от жизни в слово, которое пересоздает реальность, фиксирует миф о жизни, и способом самоотчуждения. Тем не менее обращение к письму для себя способствует открытию сложности бытия, загадки жизни, т.е. подтверждает «присутствие» человека в бытии и его стремление к постижению оного.

\section{ЛИТЕРАТУРА}

1. Чудакова М.О. Дневник // Краткая литературная энциклопедия : в 9 т. М. : Сов. энциклопедия, 1964. Т. 2. С. 707-708.

2. Оскоцкий В. Дневник как правда // Вопросы литературы. 1993. № 5. С. 9-13. 
3. Местергази Е.Г. Литература нон-фикшн / non-fiction: Экспериментальная энциклопедия. Русская версия. М. : Совпадение, 2007. 327 с.

4. Михеев М. Дневник как эго-текст. М. : Водолей Publishers, 2007. 264 c.

5. Эткинд А. Одно время я колебался, не антихрист ли я... // Новое литературное обозрение. 2005. № 3 (73). С. $27-49$.

6. Великовский С. О факте упрямом и факте податливом // Иностранная литература. 1966. № 8. С. $198-201$.

7. Палиевский П.В. Литература и теория. М. : Сов. Россия, 1979. 288 с.

8. Лотман Ю.М. Культура и взрыв. М. : Гнозис ; Прогресс, 1992. 272 с.

9. Реале Д., Антисери Д. Эдмунд Гуссерль и феноменологическое движение // Западная философия от истоков до наших дней. Т. 4: От романтизма до наших дней. СПб. : Петрополис, 1997. С. 369-385.

10. Гуссерль Э. Идеи к чистой феноменологии и феноменологической философии. М. : Академический проект, 2009.486 с.

11. Хайдеггер М. Бытие и время. М. : Академический Проект, 2011. 460 с.

12. Барт Р. Смерть автора // Избранные работы: семиотика, поэтика. М. : Универс, 1994. С. 384-391

13. Деррида Ж. О грамматологии. М. : Ad Marginem, 2000. 512 с.

14. Эпштейн М. Ноmo Scriptor: Введение в антропологию, персонологию и футурологию письма // Философские науки. 2008. № 8. С. $124-146$.

15. Лашова С. Поэтика Михаила Шишкина: система мотивов и повествовательные стратегии : автореф. дис. ... канд. филол. наук. Пермь, 2012. 22 c.

16. Кучина Т. Нарративная объективация отношений автор/герой в романе М. Шишкина «Взятие Измаила» // Альманах современной науки и образования. Тамбов : Грамота, 2007. № 3 (2). С. 107-109.

17. Брюханова Ю.М. «Живое» слово в творчестве М. Шишкина // Философия жизни в русской литературе XX-XXI веков: от жизнестроения и витальности. Иркутск : Изд-во ИГУ, 2013. С. 469-482.

18. Шатин Ю.В. «Нарратологическая пустота» в современном художественном тексте («Взятие Измаила» М. Шишкина) // Критика и семиотика. 2012. № 17. С. 311-316.

19. Шишкин М. Взятие Измаила. М. : АСТ ; Астрель, 2011. 477 с.

20. Бахтин М.М. Автор и герой в эстетической деятельности // Автор и герой: К философским основам гуманитарных наук. СПб. : Азбука, 2000. C. 9-226.

Статья представлена научной редакцией «Филология» 19 июля 2019 г.

Characters' Diaries in Mikhail Shishkin's Novel Taking Izmail

Vestnik Tomskogo gosudarstvennogo universiteta - Tomsk State University Journal, 2019, 449, 36-45.

DOI: $10.17223 / 15617793 / 449 / 5$

Alyona I. Pantyukhina, Tomsk State University (Tomsk, Russian Federation). E-mail: alena.pantuhina@yandex.ru

Keywords: diary; novel; modern Russian prose; pseudo-documentary discourse; narration; psychologism.

The study aims to analyse the ways and functions of including fragments of characters' diaries into Mikhail Shishkin's novel Taking Izmail (1999). The use of the genres of documentary literature in a work of fiction makes it possible to perceive a fictional text as a true reproduction of life phenomena, and it is a common technique in Shishkin's works, which exist at the junction of various aesthetics: realism, modernism and postmodernism. The study relies on traditional literary methods: analysis of the genre, the plot, the narration and the system of motifs that combine hermeneutic, narratological and semiotic approaches. The semantics of the diary in the novel is also considered in the philosophical aspect: in terms of phenomenology, existentialism and poststructuralism. The diary in the novel occurs twice and belongs to the minor characters: Olga Veniaminovna, the adult mistress of the still young lawyer Alexander Vasilyevich, and Vladimir Pavlovich Motte, a doctor-pathologist, who, in a situation of an imaginary court, is accused of "not helping his neighbour"; Motte is the doppelganger of Mikhail, the narrator and the protagonist of the novel, close to the former ideologically. The characters' diaries are the diaries of "I as the Other" for the narrating character (and the author), the personal and the private, recorded "for oneself", yet they are made the object of understanding, and "reading" by the author as a document of someone's phenomenal life. The inserted diary texts lose the status of documentaries. Their irreality not only reveals the character's psychological state, the destruction of their understanding of reality, but also allows the characters' subjective myths created for themselves to be interpreted as different versions of the author seeking to comprehend the world beyond his personal subjectivity. The reason for the characters' refusal from ego-writing is revealed: it is the loss of illusions for Olga Veniaminovna, and the immersion into the mythologization of reality for Motte. The analysis of the narrative fragments designated as diaries led to the following conclusions. In the novel Taking Izmail, the diary transforms, yet preserving the traditional semantics of truthfulness and psychological analysis. Firstly, the diaries are unable to reflect reality, they are not a fact of the characters' lives in time and space, i.e., they lose their function of preserving reality. Secondly, Shishkin's diary also loses its epistemological properties: it does not fix the characters' inner lives, their reflections. For the characters, the diary is a form of escapism from the awareness of the tragedy of being (existential, national, ontological), escape from life into words, it is writing that recreates reality, fixes the characters' myths. The inclusion of the characters' diaries makes it possible to challenge the postmodern interpretation of writing in Shishkin's novel as escapism and a way to overcome death.

\section{REFERENCES}

1. Chudakova, M.O. (1964) Dnevnik [Diary]. In: Surkov, A.A. (ed.) Kratkaya literaturnaya entsiklopediya: $v 9 t$. [Brief Literary Encyclopedia: In 9 Vols]. Vol. 2. Moscow: Sov. entsiklopediya. pp. 707-708.

2. Oskotskiy, V. (1993) Dnevnik kak pravda [Diary as the Truth]. Voprosy literatury. 5. pp. 9-13.

3. Mestergazi, E.G. (2007) Literatura non-fikshn / Non-Fiction: Eksperimental'naya entsiklopediya. Russkaya versiya [Non-Fiction Literature: An Experimental Encyclopedia. Russian Version]. Moscow: Sovpadenie.

4. Mikheev, M. (2007) Dnevnik kak ego-tekst [Diary as an Ego-Text]. Moscow: Vodoley Publishers.

5. Etkind, A. (2005) Odno vremya ya kolebalsya, ne antikhrist li ya... [At One Point, I Used to Wonder If I Was an Antichrist. . .]. Novoe literaturnoe obozrenie - New Literary Observer. 3 (73). pp. 27-49.

6. Velikovskiy, S. (1966) O fakte upryamom i fakte podatlivom [On a Stubborn Fact and on a Pliant Fact]. Inostrannaya literatura. 8. pp. 198-201.

7. Palievskiy, P.V. (1979) Literatura i teoriya [Literature and Theory]. Moscow: Sovetskaya Rossiya.

8. Lotman, Yu.M. (1992) Kul'tura i vzryv [Culture and Explosion]. Moscow: Gnozis; Progress.

9. Reale, G. \& Antiseri, D. (1997) Edmund Gusserl' i fenomenologicheskoe dvizhenie [Edmund Husserl and the Phenomenological Movement]. In: Reale, G. (ed.) Zapadnaya filosofiya ot istokov do nashikh dney [Western Philosophy from Its Origins to the Present]. Translated from Italian by S.A. Mal'tseva. Vol. 4. St. Petersburg: Petropolis. pp. 369-385. 
10. Husserl, E. (2009) Idei k chistoy fenomenologii i fenomenologicheskoy filosofii [Ideas for a Pure Phenomenology and Phenomenological Philosophy]. Translated from German. Moscow: Akademicheskiy proekt.

11. Heidegger, M. (2011) Bytie i vremya [Being and Time]. Translated from German. Moscow: Akademicheskiy Proekt.

12. Barthes, R. (1994) Izbrannye raboty: semiotika, poetika [Selected Works: Semiotics, Poetics]. Translated from French. Moscow: Univers. pp. 384-391.

13. Derrida, J. (2000) O grammatologii [About Grammatology]. Translated from French. Moscow: Ad Marginem.

14. Epshteyn, M. (2008) Homo Scriptor: Introduction into Scriptorics as Anthropology and Personology of Writing. Filosofskie nauki - Russian Journal of Philosophical Sciences. 8. pp. 124-146. (In Russian).

15. Lashova, S. (2012) Poetika Mikhaila Shishkina: sistema motivov i povestvovatel'nye strategii [Poetics of Mikhail Shishkin: A System of Motives and Narrative Strategies]. Abstract of Philology Cand Diss. Perm.

16. Kuchina, T. (2007) Narrativnaya ob"ektivatsiya otnosheniy avtor / geroy v romane M. Shishkina "Vzyatie Izmaila" [Narrative Objectification of the Author/Hero Relationship in M. Shishkin's Novel "Taking Izmail”]. Al'manakh sovremennoy nauki i obrazovaniya. 3 (2). pp. 107-109.

17. Bryukhanova, Yu.M. (2013) "Zhivoe" slovo v tvorchestve M. Shishkina [The "Living” Word in M. Shishkin's Works]. In: Plekhanova, I.I. (ed.) Filosofiya zhizni v russkoy literature XX-XXI vekov: ot zhiznestroeniya i vital'nosti [Philosophy of Life in the Russian Literature of the 20th-21st Centuries: From Life Building and Vitality]. Irkutsk: Irkutsk State University. pp. 469-482.

18. Shatin, Yu.V. (2012) "Narratologicheskaya pustota" v sovremennom khudozhestvennom tekste ("Vzyatie Izmaila" M. Shishkina) ["Narratological Emptiness" in a Modern Literary Text ("Taking Izmail" by M. Shishkin)]. Kritika i semiotika - Critique \& Semiotics. 17. pp. 311-316.

19. Shishkin, M. (2011) Vzyatie Izmaila [Taking Izmail]. Moscow: AST; Astrel’’

20. Bakhtin, M.M. (2000) Avtor i geroy: K filosofskim osnovam gumanitarnykh nauk [Author and Hero: Towards the Philosophical Foundations of the Humanities]. St. Petersburg: Azbuka. pp. 9-226.

Received: 19 July 2019 